\title{
ESTABILIDADE DAS DECISÕES DECLARATÓRIAS DE CONSTITUCIONALIDADE: QUANDO E COMO É CABÍVEL A REANÁLISE DA (IN)CONSTITUCIONALIDADE DE NORMA ANTERIORMENTE DECLARADA CONSTITUCIONAL ${ }^{1}$
}

\section{STABILITY OF DECLARATORY CONSTITUTIONALITY DECISIONS: WHEN AND HOW AN ANALYSIS OF THE UNCONSTITUTIONALITY OF A PREVIOUSLY LAW DECLARED AS CONSTITUTIONAL SHOULD TAKE PLACE}

Adriano Sayão Scopel

Graduado pela Faculdade de Direito da Fundação Getulio Vargas/SP. Mestrando em Direito Processual na Faculdade de Direito da Universidade de São Paulo (USP). Advogado em São Paulo/SP. E-mail: adriano.s.scopel@gmail.com

RESUMO: Abordamos a hipótese de rediscussão pelo Supremo Tribunal Federal de norma anteriormente declarada constitucional em controle abstrato e sua relação com o instituto da coisa julgada, com a conclusão de que há estabilidade nas decisões declaratórias, mas não absoluta, sob pena de petrificar a interpretação constitucional. Defendemos que as regras previstas no CPC/2015 sobre superação de precedentes podem servir de norte para a definição de quando e como deve se dar uma nova análise da (in)constitucionalidade de norma anteriormente declarada constitucional.

PALAVRAS-CHAVE: Jurisdição constitucional . Controle abstrato de constitucionalidade. Coisa julgada. Estabilidades processuais. Precedentes.

ABSTRACT: We approach the hypothesis of rediscussion by Brazilian Federal Supreme Court of a law already declared as constitutional in abstract control and its relation with the institute of the res judicata, with the conclusion that there is stability in the declaratory

\footnotetext{
${ }^{1}$ Artigo recebido em 02/12/2019 e aprovado em 27/03/2020.
} 
decisions, but not absolute, considering the risk of petrifying the constitutional interpretation. We argue that the rules set forth in CPC/2015 on overruling precedents may serve as a guide for the definition of when and how a new analysis of the (un)constitutionality of a previously law declared as constitutional should take place.

KEYWORDS: Constitutional jurisdiction. Abstract control of constitutionality. Res judicata. Procedural stabilities. Precedents.

\section{INTRODUÇÃO}

A decisão proferida pelo Supremo Tribunal Federal em controle abstrato no âmbito de ação declaratória de constitucionalidade (ADC) que reconhece a constitucionalidade de determinada norma carrega consigo a imutabilidade da coisa julgada ou pode ser objeto de posterior rediscussão em ação direta de inconstitucionalidade (ADI)? Caso se conclua pela possibilidade de nova análise da norma - o que, já adiantando uma conclusão parcial, é como entende a doutrina de forma uníssona -, quando isso possa acontecer? E quais condições deve o Supremo observar ao reanalisar a (in)constitucionalidade de norma anteriormente declarada constitucional? Estes são os questionamentos que buscamos discutir neste artigo e, para tanto, duas premissas devem ser assentadas.

A primeira premissa se relaciona com a notória expansão da proeminência do Poder Judiciário no sistema jurídico brasileiro. A sociedade contemporânea é altamente conflitiva², do que decorre a excessiva judicialização de conflitos em instâncias ordinárias e, para o que nos interessa no presente ensaio, a intensa judicialização da política ${ }^{3}$ e de normas editadas pelos Poderes Legislativo e Executivo. Com isso, o Supremo Tribunal Federal é cada vez

\footnotetext{
2 Ada Pellegrini Grinover, Ensaio sobre a processualidade: fundamentos para uma nova teoria geral do processo, Brasília: Gazeta Jurídica, 2018, p. 33.

${ }^{3}$ Não se confunda o termo judicialização da política com politização do judiciário, este intrinsicamente ligado ao fenômeno do ativismo judicial, caracterizado como um "atalho pernicioso" por Gilmar Ferreira Mendes e Georges Abboud: "Nenhum entusiasmo ou desejo de mudança pode suplantar o direito aprovado pelas regras democráticas. Juízes não são, diretamente, agentes de transformação da realidade. Juízes são protetores do direito, podendo agir, inclusive, de forma contramajoritária para tanto. Juízes asseguram as regras do jogo e a estabilidade democrática, para assim possibilitar que a transformação da realidade opere nas instâncias adequadas. O ativismo, enfim, é um atalho pernicioso para fazer valer um determinado ponto de vista político, sem que se percorra o imprevisível e necessário caminho do dissenso." ("Ativismo judicial: notas introdutórias a uma polêmica contemporânea", in Revista dos Tribunais, vol. 1008, Out./2019, p. 6).
} 
mais instado a se manifestar sobre a (in)constitucionalidade de normas em ações de controle abstrato - e muitas vezes sobre questões já anteriormente apreciadas pela Corte.

A segunda premissa é a de que embora seja a estabilidade das decisões, e em particular das declarações de constitucionalidade, um objetivo a ser alcançado em nome da segurança jurídicas, é fato que o dinamismo das relações sociais pode - e muitas vezes deve - provocar mudanças na interpretação da Constituição. ${ }^{4}$ Assim, mudanças de entendimento do Supremo sobre a constitucionalidade de normas (por exemplo, considerar inconstitucional uma lei anteriormente declarada como constitucional) não devem necessariamente ser vistas como anomalias per se.

Nesse contexto, o caminho a ser percorrido neste artigo inicia-se com (1) breve exame das características da ADI e da ADC como ações de controle abstrato de constitucionalidade de normas. Em seguida, (2) passaremos à análise da relação do instituto da coisa julgada com as hipóteses de ações de controle abstrato e (3) ao exame de posições doutrinárias sobre a estabilidade de tais decisões e da possibilidade de inconstitucionalidade de norma anteriormente declarada constitucional. Finalmente, a partir da conclusão parcial já adiantada de que a decisão declaratória de constitucionalidade não recebe o grau máximo de imutabilidade, (4) discorreremos sobre as formas de proteção da estabilidade de tais decisões, ou seja, quais condições o Supremo deve observar para poder examinar novamente uma norma já declarada constitucional.

Cabe também a ressalva de que o estudo das estabilizações de decisões na jurisdição constitucional é amplo e apresenta diversas vias de análise. Podemos pensar, a título exemplificativo, em casos de anterior declaração de inconstitucionalidade e posterior declaração de constitucionalidade, ou anterior declaração de descumprimento de preceito fundamental e posterior possibilidade de modificação da declaração. $\mathrm{O}$ escopo deste artigo

\footnotetext{
${ }^{4}$ Em ensaio publicado há mais de seis décadas, Konrad Hesse já apontava que "se o direito e, sobretudo, a Constituição, têm a sua eficácia condicionada pelos fatos concretos da vida, não se afigura possível que a interpretação faça deles tábula rasa. Ela há de contemplar essas condicionantes, correlacionando-as com as proposições normativas da Constituição. A interpretação adequada é aquela que consegue concretizar, de forma excelente, o sentido (Sinn) da proposição normativa dentro das condições reais dominantes numa determinada situação." (A força normativa da constituição, Porto Alegre: Safe, 1991, pp. 22-23). Sobre a chamada mutação constitucional, Gilmar Ferreira Mendes dá como exemplo de maior relevância histórica a interpetração da Suprema Corte dos Estados Unidos sobre questões envolvendo igualdade racial: "Em 1896, no caso Plessy versus Ferguson, a Corte Suprema americana reconheceu que a separação entre brancos e negros em espaços distintos, no caso específico em vagões de trens, era legítima. Foi a consagração da fórmula equal but separate. Essa orientação veio a ser superada no já clássico Brown versus Board of Education (1954), no qual se assentou a incompatibilidade dessa separação com os princípios básicos da igualdade." (Jurisdição constitucional: o controle abstrato de normas no Brasil e na Alemanha, 6ª ed., São Paulo: Saraiva, 2014, p. 465).
} 
Rio de Janeiro. Ano 15. Volume 22. Número 1. Janeiro a Abril de 2021

Periódico Quadrimestral da Pós-Graduação Stricto Sensu em Direito Processual da UERJ

Patrono: José Carlos Barbosa Moreira (in mem.). ISSN 1982-7636. pp. 29-57

www.redp.uerj.br

abrange tão somente $\mathrm{o}$ exame da estabilidade de decisões declaratórias de constitucionalidade - assim consideradas como as de procedência em ADC - e a possibilidade de revisão do quanto decidido em posterior ADI.

\section{BREVES CONSIDERAÇÕES SOBRE O MECANISMO DE CONTROLE} ABSTRATO DE CONSTITUCIONALIDADE

O sistema jurídico brasileiro adotou o modelo híbrido de controle de constitucionalidade das normas, que pode se dar, basicamente, por duas formas: (1) no julgamento de caso concreto, em que se afirma ou se nega aplicação a norma para tutelar direito específico (controle incidental e difuso), e (2) no julgamento de ação direta, na qual mediante poder avocatório do Supremo Tribunal Federal se declara a inconstitucionalidade ou a constitucionalidade de determinado preceito normativo em face da Constituição (controle abstrato e concentrado). ${ }^{5}$

O controle abstrato das normas pelo Supremo é previsto na alínea "a", inciso I, do art. 102, da Constituição Federal, que determina a competência da Corte para processar e julgar, originalmente, "a ação direta de inconstitucionalidade de lei ou ato normativo federal ou estadual e a ação declaratória de constitucionalidade de lei ou ato normativo federal." $\mathrm{O}$ traço fundamental de tais ações é o exame de compatibilidade da norma com a Constituição, sem qualquer relação com um conflito jurídico concreto, daí o seu caráter abstrato, posto que é a norma em si o objeto central (e não causa de pedir) da questão em debate. Em outras palavras, trata-se de processo que não se presta a resolver situações jurídicas individuais, e até por isso diz-se que se trata de processo sem partes.

Historicamente no Brasil o controle de constitucionalidade pelo Supremo era predominantemente realizado de modo incidental, uma vez que a legitimação para propositura de ação de controle abstrato era restrita ao Procurador-Geral da República ${ }^{6}$, que por sua vez era diretamente vinculado ao Poder Executivo. ${ }^{7}$ Com a promulgação da

\footnotetext{
5 Teori Albino Zavascki, Eficácia das sentenças na jurisdição constitucional, $4^{\mathrm{a}}$ ed., São Paulo: Editora Revista dos Tribunais, 2017, pp. 23-24.

${ }^{6}$ A Emenda Constitucional n. 16/1965 introduziu no texto da Carta de 1946 o sistema de controle abstrato de normas, alterando a redação do art. 101, I, alínea "k": "[Ao Supremo Tribunal Federal compete processar e julgar originariamente:] a representação contra inconstitucionalidade de lei ou ato de natureza normativa, federal ou estadual, encaminhada pelo Procurador-Geral da República."

${ }^{7}$ Gilmar Ferreira Mendes relata uma situação em que ficou muito bem delineado o caráter "manco" da previsão de ação direta de inconstitucionalidade restrita ao Procurador-Geral da República: "Em 1970, o MDB, único
} 
Constituição de 1988, no entanto, houve substancial ampliação dos legitimados para a propositura de ações abstratas; o rol dos incisos do art. 103 inclui diversos legitimados além do Procurador-Geral da República, com destaque para Governadores de Estado, partidos políticos com representação no Congresso Nacional e confederações sindicais ou entidades de classe de âmbito nacional. Isso permitiu que praticamente todas as controvérsias constitucionais relevantes sejam submetidas ao Supremo mediante processo de controle abstrato de normas. ${ }^{8}$

Além da ADI e da ADC, também fazem parte do rol de ações de controle abstrato a arguição de descumprimento de preceito fundamental (ADPF), prevista no $\S 1^{\circ}$ do art. 102 da Constituição e na Lei 9.882/1999, a ação direta de inconstitucionalidade por omissão, disciplinada no art. 12-A e seguintes da Lei 9.868/1999, e finalmente, a praticamente esquecida dada sua relativa desimportância ${ }^{9}$, ação direta interventiva. Contudo, nos limites propostos por este artigo não analisaremos os contornos da estabilidade destas decisões, restringindo-nos a questão envolvendo as relações entre ADI e ADC.

\subsection{ADC, ADI E A NATUREZA DÚPLICE DESTAS AÇÕES}

A ADC não foi obra do constituinte originário de 1988, mas sobreveio ao sistema brasileiro com a promulgação da Emenda Constitucional 3/1993, que alterou o já citado art. 102, I, "a", da Constituição, que antes previa apenas a ADI como instrumento de controle abstrato e concentrado. À parte a tradição do direito brasileiro de atribuição de presunção de constitucionalidade das normas, trata a ADC de medida que busca afastar incerteza jurídica e estabelecer uma orientação homogênea na matéria em discussão ${ }^{10}$, mediante reconhecimento de compatibilidade de determinada norma com a Constituição.

partido de oposição representado no Congresso Nacional, solicitou ao Procurador-Geral da República a instauração do controle abstrato de normas contra o decreto-lei que legitimava a censura prévia de livros, jornais e periódicos. Este negou-se a submeter a questão ao Supremo Tribunal Federal, uma vez que, na sua opinião, não estava constitucionalmente obrigado a fazê-lo." (Jurisdição constitucional: o controle abstrato de normas no Brasil e na Alemanha. 6a ed., São Paulo: Saraiva, 2014, pp. 95-96).

${ }^{8}$ Gilmar Ferreira Mendes. Jurisdição constitucional: o controle abstrato de normas no Brasil e na Alemanha. Op. Cit., p. 114.

${ }^{9}$ Luís Roberto Barroso, O controle de constitucionalidade no direito brasileiro: exposição sistemática da doutrina e análise crítica da jurisprudência, $8^{\text {a }}$ ed., São Paulo: Saraiva, 2019, p. 405.

${ }^{10}$ Luís Roberto Barroso, O controle de constitucionalidade no direito brasileiro: exposição sistemática da doutrina e análise crítica da jurisprudência, Op. cit., p. 308. 
Pela leitura do dispositivo constitucional depreende-se uma diferença na amplitude das ferramentas processuais, na medida em que a ADC é cabível em face de lei ou ato normativo federal, ao passo que a ADI pode ser proposta contra lei ou ato normativo federal ou estadual. Por outro lado, as similitudes são diversas; o rol de legitimados para propor ADI e ADC são os mesmos e a Lei 9.868/1999, que disciplina os dois instrumentos, contém diversos dispositivos em comum - como a regra dos efeitos das decisões e de possível modulação, que serão analisados mais adiante.

Com base nas semelhanças entre ADI e ADC, a doutrina majoritária considera que as ações têm natureza dúplice, na medida em que ambas têm aptidão para firmar juízo de constitucionalidade ou de inconstitucionalidade. ${ }^{11} \mathrm{~A}$ esse respeito, Teori Albino Zavascki sustenta que "a natureza dúplice das ações de controle concentrado evidencia, destarte, que qualquer delas é, ao mesmo tempo, instrumento para afirmação do direito, quando declara a constitucionalidade de suas normas, e de 'autopurificação' do direito, quando declara a sua inconstitucionalidade. ${ }^{\prime 12}$ Em outras palavras, a procedência de uma ADC seria equivalente a improcedência de ADI, e vice-versa.

\subsection{EFICÁCIA ERGA OMNES E EFEITO VINCULANTE DAS DECISÕES EM ADC OU ADI}

Igualmente em relação aos efeitos que projetam há semelhanças entre ADC e ADI. Conforme prescreve o $\S 2^{\circ}$ do art. 102 da Constituição, tais decisões "produzirão eficácia contra todos e efeito vinculante, relativamente aos demais órgãos do Poder Judiciário e à administração pública direta e indireta, nas esferas federal, estadual e municipal."13 A

\footnotetext{
${ }^{11} C f$. art. 24 da Lei 9.868/1999: “Art. 24. Proclamada a constitucionalidade, julgar-se-á improcedente a ação direta ou procedente eventual ação declaratória; e, proclamada a inconstitucionalidade, julgar-se-á procedente a ação direta ou improcedente eventual ação declaratória."

${ }^{12}$ Eficácia das sentenças na jurisdição constitucional, Op. cit., p. 60. No mesmo sentido, Luís Roberto Barroso defende que ADI e ADC fazem parte da mesma unidade conceitual, "como se fossem ações em tudo idênticas, apenas com 'sinal trocado" ( $O$ controle de constitucionalidade no direito brasileiro: exposição sistemática da doutrina e análise crítica da jurisprudência, Op. cit., p. 270). Em posição contrária, Georges Abboud defende que "o julgamento improcedente da ADIn não deve autorizar a declaração de constitucionalidade do ato normativo em questão" (Processo constitucional brasileiro, $3^{\mathrm{a}}$ ed., São Paulo: Thomson Reuters Brasil, 2019, p. 518).

${ }^{13}$ O dispositivo constitucional é replicado, com poucas diferenças, na Lei 9.868/1999: “Art. 28. (...) Parágrafo único. A declaração de constitucionalidade ou de inconstitucionalidade, inclusive a interpretação conforme a Constituição e a declaração parcial de inconstitucionalidade sem redução de texto, têm eficácia contra todos e efeito vinculante em relação aos órgãos do Poder Judiciário e à Administração Pública federal, estadual e municipal."
} 
eficácia contra todos consiste no caráter erga omnes da decisão, ou seja, da irradiação de efeitos para todos os possíveis destinatários da norma.

Por seu turno, o efeito vinculante diz respeito à respeitabilidade da decisão. Segundo Zavascki, o efeito vinculante confere ao julgado uma força obrigatória, "com a consequência processual de assegurar, em caso de recalcitrância, a utilização de um mecanismo executivo próprio - a reclamação - para impor o seu cumprimento."14 Resta, porém, entender efetivamente a quem se destina essa eficácia vinculante. Naturalmente, ante o texto expresso do dispositivo constitucional, não há margem para discussão de que os órgãos do Poder Judiciário e Executivo ficam vinculados ao quanto decidido na ação abstrata; mas e o Poder Legislativo e o próprio Supremo?

No que se refere ao Poder Legislativo, entende-se que a ausência de menção no dispositivo constitucional configura a sua exclusão do alcance do efeito vinculante ${ }^{15}$, de forma que a declaração de constitucionalidade ou de inconstitucionalidade não impediria o legislador futuro de editar norma de conteúdo igual ou análogo ao que foi rejeitado. ${ }^{16}$

Exemplo concreto e amplamente noticiado nesse sentido deu-se com a discussão sobre a prática popularmente conhecida como vaquejada. Em apertada síntese, dado que a questão é deveras complexa e repleta de nuances, a sequência de fatos foi a seguinte: (1) em 2016, o Supremo julgou procedente a ADI 4983 - decisão que, portanto, produziu efeitos erga omnes e vinculante -, proposta contra lei estadual do Ceará que regulamentava a vaquejada como prática desportiva e cultural, por entender que havia "crueldade intrínseca" aplicada aos animais; (2) irresignado, o Poder Legislativo procurou contornar a declaração de inconstitucionalidade ${ }^{17}$, promulgando a Emenda Constitucional 96/2017, que acrescentou

\footnotetext{
${ }^{14}$ Eficácia das sentenças na jurisdição constitucional, Op. cit., p. 66.

15 "O Poder Legislativo ficou excluído da dicção e do alcance do efeito vinculante previsto no parágrafo único do art. 28 da Lei n. 9.868/99 e no art. 102, § 2º da Constituição.” (Luís Roberto Barroso, O controle de constitucionalidade no direito brasileiro: exposição sistemática da doutrina e análise crítica da jurisprudência, Op. cit., p. 308). A esse respeito, vale o destaque de Barroso - usando o sistema francês como exemplo - de que em certos sistemas constitucionais a decisão de inconstitucionalidade impede o legislador futuro de editar norma de conteúdo igual ou análogo ao que foi rejeitado.

${ }^{16}$ Interessante observação acerca do assunto é levantada por Georges Abboud, que embora concordando com a não vinculação do legislador às decisões proferidas em ADC ou ADI, menciona a possibilidade de responsabilização do legislador por reeditar lei declarada inconstitucional: "caso o Legislativo persista teimosamente na promulgação da lei anteriormente declarada inconstitucional, ignorando sem motivo justificado o sentido da jurisprudência constitucional, será possível uma ação de responsabilidade civil pelo ilícito legislativo, a fim de demonstrar a conduta ilícita do legislador." (Processo constitucional brasileiro, Op. cit., pp. 628-629).

17 Discorrendo sobre a discussão em tese, sem referir-se especificamente ao caso da vaquejada, Zavascki entende que é legítima a atuação do Legislativo dessa maneira: "Ora, não se pode negar ao constituinte, que pode mais, o que é dado ao legislador ordinário, que pode menos. Assim, nada impede que a aprovação da
} 
o $\$ 7^{\circ}$ ao art. 225 da Constituição para determinar que práticas desportivas que utilizem animais não são consideradas cruéis; e (3) ato contínuo, no mesmo ano de 2017, foi proposta ADI (ainda não julgada) para questionar a emenda constitucional que permitiu a prática da vaquejada - destaque-se, para o que nos interessa no presente artigo, que o autor da ADI fundamenta seu pedido com base em violação de cláusulas pétreas, não alegando eventual violação ao efeito vinculante da decisão do Supremo que havia considerado a inconstitucionalidade da prática da vaquejada. Ou seja, reconhecendo que o efeito vinculante de decisão em controle concentrado de constitucionalidade não atinge o Poder Legislativo.

Quanto aos efeitos vinculantes das decisões em ADC e ADI ao próprio Supremo, parece-nos que não há que se falar em autovinculação, sob pena de petrificar a interpretação constitucional - legitima esse entendimento o fato de o $\S 2^{\circ}$ do art. 102 da Constituição fazer expressa referência de efeito vinculante aos demais órgãos do Poder Judiciário. Mas essa é uma discussão que envolve o exame do instituto da coisa julgada e outras estabilidades processuais e que justifica uma apreciação mais detida. É o que faremos no item a seguir.

\section{AINDA E SEMPRE A COISA JULGADA ${ }^{18}$ : SUA RELAÇÃO COM AS AÇÕES DE CONTROLE ABSTRATO DE CONSTITUCIONALIDADE}

"Poder-se-ia dizer que, se a coisa julgada não existisse em um ordenamento jurídico, haveria que inventá-la, porque é perfeitamente inimaginável a insegurança jurídica que se derivaria da sua inexistência." Os ensinamentos de Jordi Nieva-Fenoll ${ }^{19}$, ecoados pela doutrina brasileira ${ }^{20}$, mostram a importância do instituto da coisa julgada, alçado a garantia

\footnotetext{
norma semelhante à anterior seja promovida na própria Emenda à Constituição, mediante a reprodução de seu texto ou mediante a fórmula de remissão expressa. Isso representa, em substância e na prática, a convalidação, com efeito ex nunc, da lei anteriormente inconstitucional, o que, portanto, nesses limites, não é vedado ao constituinte." (Eficácia das sentenças na jurisdição constitucional, Op. cit., p. 138).

${ }^{18} \mathrm{O}$ título do capítulo é uma remissão/homenagem ao clássico texto de Barbosa Moreira (Ainda e sempre a coisa julgada, in Revista dos Tribunais, vol. 416/9, Jun./1970).

${ }^{19}$ Coisa Julgada, São Paulo: Editora Revista dos Tribunais, 2016, p. 89.

${ }^{20}$ Luiz Guilherme Marinoni, A intangibilidade da coisa julgada diante da decisão de inconstitucionalidade: art. 525, §\$ 12, 13, 14 e 15 do CPC/2015, $4^{\text {a }}$ ed., São Paulo: Editora Revista dos Tribunais, 2016, p. 53: "Sendo indispensável à afirmação da autoridade do Estado, a coisa julgada é, ainda, inerente ao Estado Constitucional. Pouco importaria se a coisa julgada não houvesse sido resguardada de forma expressa pela Constituição Federal brasileira, pois deriva do Estado de Direito e encontra base nos princípios da segurança jurídica e da proteção da confiança." No mesmo sentido, Antonio do Passo Cabral, "As estabilidades processuais como categoria incorporada ao sistema do CPC", in Coisa julgada e outras estabilidades processuais, Salvador: Ed. JusPodivm, 2018, p. 37: "Se fossem revogados os arts. 502 a 508 do CPC, que disciplinam a coisa julgada material, as decisões judiciais de mérito deixariam de ser protegidas por qualquer tipo de estabilidade? Claro que a resposta só pode ser negativa."
} 
fundamental na Constituição de 1988 (art. 5, XXXVI). No âmbito da legislação ordinária, a coisa julgada é definida no art. 502 do CPC/2015 como a autoridade que torna imutável e indiscutível a decisão de mérito não mais sujeita a recurso.

Feitas estas brevíssimas considerações, cabe agora examinar como se relaciona o instituto da coisa julgada com as decisões declaratórias de constitucionalidade, a fim de refletir se há imutabilidade nestas decisões ou - como sugere o título do artigo - se é cabível a sua revisão, ou seja, a declaração de inconstitucionalidade de norma anteriormente confirmada como constitucional no âmbito de ADC.

\subsection{COISA JULGADA (OU ESTABILIDADE) E DECISÃO DECLARATÓRIA DE CONSTITUCIONALIDADE}

A decisão do Supremo Tribunal Federal que julga procedente uma ADC é irrecorrível - ressalvadas as hipóteses de oposição de embargos de declaração, nos restritos limites intrínsecos a este tipo de recurso - e não pode ser objeto de ação rescisória (Lei 9.868/1999, art. 26). Demais disso, e conforme já delineado, referida decisão tem eficácia contra todos e efeito vinculante, relativamente aos demais órgãos do Poder Judiciário e à administração pública direta e indireta, nas esferas federal, estadual e municipal. Há, portanto, fortes indícios de que a decisão declaratória de constitucionalidade tenha que ser estável, mas não se pode inferir uma obrigatoriedade de imutabilidade e indiscutibilidade da decisão.

Ora, é princípio básico da coisa julgada, em seu aspecto positivo, a proibição da reiteração de juízos, visto que a segurança jurídica dialoga diretamente com a premissa de que sobre cada assunto somente se possa decidir uma única vez. ${ }^{21}$ No caso da ADC, logo em sua primeira apreciação perante o Supremo ${ }^{22}$, a discussão sobre a estabilidade da decisão veio à tona, em manifestação do Ministro Carlos Velloso: "Alterando-se a constituição substancial, a esta há de ajustar-se a constituição formal. Daí porque interpreto a norma inscrita na Emenda Constitucional n. 3, de 1993, que estabelece a eficácia erga omnes para a decisão que resolve em definitivo a ação declaratória de constitucionalidade, cum grano salis. Quer dizer, a declaração de constitucionalidade da lei não impede, a meu ver, diante

\footnotetext{
${ }^{21}$ Jordi Nieva-Fenoll, Coisa Julgada, Op. cit., p. 135.

22 ADC-QO 1, Rel. Min. Moreira Alves, j. em 27/10/1993, publicado em 16/06/1995.
} 
de alteração das circunstâncias fáticas ou da realidade normativa, a propositura da ação direta de inconstitucionalidade. Penso que esta é uma posição que a Corte constitucional deve assentar. É que, como foi dito: hoje, a lei pode ser constitucional, amanhã, não.”

O trecho final acima transcrito é sintomático e por sua importância e poder de síntese justifica uma repetição: hoje, a lei pode ser constitucional, amanhã, não. Ou seja, há um reconhecimento expresso da premissa de que a interpretação constitucional é mutável. Não há que se ter posição definitiva em relação à constitucionalidade de uma norma; o julgamento do Supremo em uma ADC é uma fotografia à luz da hermenêutica, valores e conceitos jurídicos à época da decisão, pelo que a formação de coisa julgada material não é compatível com decisões declaratórias de constitucionalidade.

Nesse sentido, Georges Abboud, alertando para o risco de fossilização da Constituição, afirma que não deve ser admitida a coisa julgada material, nos termos do processo civil comum, para situações de jurisdição constitucional de ações abstratas. Nas palavras de Abboud, "da mesma forma que o Legislativo não pode decidir que uma lei, em abstrato, não pode ter sua inconstitucionalidade aventada no tempo, igualmente não pode $\mathrm{o}$ Supremo, principal servo da Constituição, em declarando a constitucionalidade, embutir o selo de coisa julgada material nessa declaração, buscando impedir que a inconstitucionalidade de determinada lei seja alegada no tempo."23

Em obra específica sobre o assunto, Renann Faria Kruger também refuta a formação de coisa julgada no controle abstrato de constitucionalidade, ante a inaplicabilidade do conceito clássico de coisa julgada ${ }^{24}$ e, portanto, a inocorrência de imutabilidade e consequente indiscutibilidade de decisão proferida pelo Supremo.

\footnotetext{
${ }^{23}$ Processo constitucional brasileiro, Op. cit., p. 652.

24 "Como fundamento para a inexistência da coisa julgada, observa-se a dicotomia de modelos, pois o controle de constitucionalidade abstrato é processo objetivo de natureza não subjetiva, modelo de processo que não se ajusta às teorizações da coisa julgada, já que este vem pensada desde sua formação clássica para estabilização de decisões que resolvem uma lide de interesses intersubjetivos. Tentar fazer aplicar instituto pensando para o processo subjetivo no objetivo traz quebra de sistema e, ainda mais, inadequação e confusão. Assim, como processo objetivo que é o controle abstrato, vislumbra-se, sim, o controle em tese e abstrato da (in)constitucionalidade e do (des)cumprimento de preceito fundamental e não o interesse intersubjetivo individual ou coletivo." (Renann Faria Kruger Thamay, A coisa julgada no controle de constitucionalidade abstrato, São Paulo: Atlas, 2015, p. 298). Também nessa linha, Igor Bimkowski Rossoni, em monografia sobre coisa julgada e controle de constitucionalidade, defende que na jurisdição constitucional deve-se dar prevalência à interpretação mais adequada acerca da constitucionalidade da norma, em detrimento do princípio da imutabilidade do julgado. O paralelo traçado é com os processos ordinariamente levados ao conhecimento do Poder Judiciário, cujo objetivo é a obtenção de decisão que solucione o caso concreto. Para estes, ao contrário do que se dá quando da declaração de constitucionalidade de determinado ato normativo, "o valor certeza se sobrepõe à busca pela justiça ou verdade" (Coisa julgada e controle de constitucionalidade. Dissertação de mestrado apresentada à Faculdade de Direito da Universidade de São Paulo, 2013, p. 186).
} 
As observações parecem-nos irrefutáveis, pelo que a discussão sobre a não formação de coisa julgada, na acepção do art. 502 do CPC, às decisões declaratórias de constitucionalidade pode ser considerada superada. No entanto, é evidente que certo grau de estabilidade é necessário em tais decisões. E isso é plenamente possível, pois embora seja a coisa julgada a forma mais clássica de estabilidade processual, ela não é a única. Nas lições de Cândido Rangel Dinamarco, uma decisão não amparada pela coisa julgada não é sinônimo de decisão desprovida de qualquer imunização, vez que "a coisa julgada é o maior grau imaginável de imunização dos atos processuais, mas não é a única barreira imunizadora." ${ }^{25}$ No mesmo sentido, Antonio do Passo Cabral discorre sobre a existência de várias espécies de estabilidade e aponta o equívoco de pensar que estabilidade processual é sinônimo de coisa julgada. ${ }^{26}$ Logo, há que se falar na existência de mecanismos diferenciados para as estabilidades processuais, com regimes e requisitos mais ou menos rígidos.

Ao cabo destas considerações, afastada a maniqueísta ideia de que a ausência de formação de coisa julgada significa uma espécie de anarquia que permite a revisão constante das decisões, torna-se mais fácil de assimilar que, embora não absoluta, há estabilidade nas decisões no campo do controle abstrato de constitucionalidade.

\section{DECLARAÇÃO DE CONSTITUCIONALIDADE E POSTERIOR REAPRECIAÇÃO PELO SUPREMO: ANÁLISE DE POSIÇÕES DOUTRINÁRIAS}

É, pois, nesse contexto de diferentes estabilidades no sistema processual brasileiro sendo a coisa julgada a mais forte, mas não a única - que retornamos ao questionamento feito na introdução deste artigo. Se se considera que a decisão que declara a constitucionalidade de determinada norma em ADC deve ser estável, em nome da segurança jurídica e em vista de seu efeito vinculante, mas que ao mesmo tempo não há imutabilidade absoluta da decisão, indagamos se há consenso na doutrina sobre quando e como pode o Supremo reanalisar a mesma norma para, eventualmente, declará-la inconstitucional.

\footnotetext{
${ }^{25}$ Instituições de direito processual civil: volume III, $8^{\mathrm{a}}$ ed., São Paulo: Malheiros, 2019, p. 369.

26 'Trata-se de um 'cacoete' acadêmico, que é imaginar que ou temos coisa julgada ou nada; ou há coisa julgada, e portanto se torna um conteúdo estável no processo, ou não há coisa julgada, e tudo está em aberto podendo ser revisto." "“As estabilidades processuais como categoria incorporada ao sistema do CPC", Op. cit., p. 36).
} 


\subsection{POSIÇÃO DE GILMAR FERREIRA MENDES}

Em clássico estudo comparativo sobre o controle abstrato de normas na Alemanha e no Brasil, Gilmar Ferreira Mendes é enfático ao afirmar que as decisões declaratórias não podem ter estabilidade absoluta. A esse respeito, relata que semelhante questão suscitou controvérsias na Alemanha, prevalecendo, ao fim, o entendimento de que o Tribunal tedesco (Bundesverfassungsgericht) poderia vir a declarar, posteriormente, a inconstitucionalidade da norma declarada constitucional. ${ }^{27}$

Nesse sentido, ainda de acordo com Mendes, com suporte na doutrina alemã de BrunOtto Bryde, "se se considera que o direito e a própria Constituição estão sujeitos à mutação e, portanto, que uma lei declarada constitucional pode vir a tornar-se inconstitucional, temse de admitir a possibilidade de a questão já decidida poder ser submetida novamente à Corte Constitucional. Se se pretendesse excluir tal possibilidade, ter-se-ia a exclusão dessas situações, sobretudo das leis que tiveram sua constitucionalidade reconhecida pela Corte Constitucional, do processo de desenvolvimento constitucional, ficando elas congeladas no estágio do parâmetro de controle à época da aferição."28

Ou seja, o risco de petrificação do direito mencionado anteriormente neste artigo é confrontado com um bem maior que é o desenvolvimento (mutação) da interpretação constitucional, o que serve como gancho para que seja suscitado perante o Supremo a inconstitucionalidade de norma anteriormente declarada constitucional. "As sentenças" prossegue Mendes - "contêm implicitamente a cláusula rebus sic standibus, de modo que as alterações posteriores que alterem a realidade normativa, bem como eventual modificação da orientação jurídica sobre a matéria, podem tornar inconstitucional norma anteriormente considerada legítima (inconstitucionalidade superveniente)."29

Por fim, parece-nos claro que Mendes defende que, em que pese possível, a reapreciação pelo Supremo de uma norma anteriormente declarada inconstitucional é algo não trivial e inclusive por isso à Corte incumbe o ônus argumentativo de demonstrar quando

\footnotetext{
27 “A força de lei (Gesetzeskraft) da decisão do Bundesverfassungsgericht que confirma a constitucionalidade revelar-se-ia problemática se o efeito vinculante geral, que se lhe reconhece, impedisse que o Tribunal se ocupasse novamente da questão." (Jurisdição constitucional: o controle abstrato de normas no Brasil e na Alemanha, Op. cit., p. 410).

${ }^{28}$ Jurisdição constitucional: o controle abstrato de normas no Brasil e na Alemanha, Op. cit., p. 413.

${ }^{29}$ Jurisdição constitucional: o controle abstrato de normas no Brasil e na Alemanha, Op. cit., p. 476.
} 
a quebra da estabilidade da primeira decisão deve ser mitigada. Há que se fazer, portanto, uma crítica fundada do entendimento anterior, que explicite e justifique a mudança. ${ }^{30}$

\subsection{POSIÇÃO DE TEORI ALBINO ZAVASCKI}

Por seu turno, Zavascki afirma que as sentenças de mérito que declaram a constitucionalidade da norma, ou seja, as de improcedência em ADI e as de procedência em ADC estão cobertas pela coisa julgada. ${ }^{31}$ Mas reconhecendo que a imutabilidade não é absoluta, e em vista da impossibilidade de ação rescisória, afirma que dois questionamentos subsistem; um relacionado a fatos anteriores à primeira decisão (que declarou a constitucionalidade de norma em ADC, por exemplo) e outro que diz respeito a eventos supervenientes.

O primeiro questionamento foi resumido por Zavascki na seguinte indagação: declarada a constitucionalidade da norma, seria admissível um novo pedido de declaração de inconstitucionalidade à luz de fundamentos diversos dos invocados no julgado anterior? Ou seja, sem nenhuma alteração no contexto fático-jurídico da sociedade, haveria que se cogitar novo questionamento da constitucionalidade de norma, fundado, por exemplo, em ofensa a outro dispositivo constitucional?

A resposta do saudoso processualista é negativa, pois a repetição dos pedidos "atenta contra a coisa julgada". ${ }^{32}$ Argumenta Zavascki, à luz do princípio jura novit curia, que na ADC ou na ADI a causa de pedir é aberta, pelo que a indicação pelo demandante de determinado dispositivo constitucional que supõe violado não impede a cognição do Supremo de eventual ofensa à Constituição como um todo. Assim, "declarada a procedência ou a improcedência da ação declaratória de constitucionalidade ou da ação direta de

\footnotetext{
${ }^{30}$ Jurisdição constitucional: o controle abstrato de normas no Brasil e na Alemanha, Op. cit., p. 488.

${ }^{31}$ Eficácia das sentenças na jurisdição constitucional. Op. cit., p. 122.

${ }^{32}$ Eficácia das sentenças na jurisdição constitucional. Op. cit., p. 124. Interessante notar que Zavascki aponta que isso não ocorre em outros países que têm forte influência no sistema processual brasileiro. ${ }^{32}$ Assim, na Itália, rejeitada uma arguição de inconstitucionalidade, "nada impede que se volte a impugnar a mesma norma, invocando outros parâmetros constitucionais ou denunciando outros vícios de ilegitimidade, diferentes dos motivos de censura anteriormente postos a exame da Corte Constitucional." O mesmo ocorre na Espanha ("a sentença que rejeita a arguição não confere à norma questionada uma presunção reforçada de constitucionalidade e nem a torna insuscetível de ulterior controle de constitucionalidade") e em Portugal ("as decisões de não inconstitucionalidade apenas fazem caso julgado formal, porquanto nem sequer têm força de caso julgado material, na medida em que não impedem que o mesmo requerente volte a solicitar ao Tribunal a apreciação da constitucionalidade da norma anteriormente não declarada inconstitucional).”
} 
inconstitucionalidade, haverá coisa julgada material insuscetível de ser modificada mediante nova ação, ainda que com outro fundamento legal. Aplica-se à hipótese o princípio segundo o qual a coisa julgada opera a preclusão do deduzido e do dedutível, que inspirou o art. 508 do CPC: 'transitada em julgado a decisão de mérito, considerar-se-ão deduzidas e repelidas todas as alegações e as defesas que a parte poderia opor tanto ao acolhimento quando à rejeição do pedido." "33

Por sua vez, o segundo questionamento é relacionado a eventos posteriores à decisão que declara a constitucionalidade da norma: sobrevindo alteração do estado de fato ou de direito, com reflexos na vigência ou na própria constitucionalidade da norma validada pela sentença, como desfazer a força vinculativa da coisa julgada? A indagação parte da premissa de Zavascki, compartilhada por Gilmar Ferreira Mendes como visto no item anterior, de que as decisões que declaram a constitucionalidade das normas estão sujeitas à cláusula rebus sic standibus, pelo que a controvérsia que remanesce consiste na conceituação do que exatamente seria a manutenção do estado de fato e de direito que serviu de pressuposto no julgamento.

Ao contrário de Mendes, no entanto, Zavascki ocupou-se de tentar esmiuçar o que efetivamente seria mudança no estado de direito, defendendo que se trata da hipótese de reforma da Constituição vigente à época da primeira decisão. ${ }^{34}$ Trazendo a premissa teórica para um exemplo concreto, podemos novamente pensar na discussão envolvendo a vaquejada; o Supremo tem, novamente, um encontro marcado com uma controvérsia que já foi decidida pela Corte, mas agora com uma mudança no estado de direito, consistente na emenda que deu status constitucional à prática da vaquejada.

Já para descrever as mudanças no estado de fato, Zavascki foi mais lacônico, corroborando a possibilidade de inconstitucionalidade superviente - "uma norma nascida em harmonia com a Constituição pode tornar-se com ela incompatível em face de

\footnotetext{
${ }^{33}$ Eficácia das sentenças na jurisdição constitucional. Op. cit., pp. 125-126. A única exceção descrita por Zavascki é no caso de nova ação com base em inconstitucionalidade formal: "quando eventual vício formal que compromete a constitucionalidade da norma decorre do fato que o Tribunal não conhecia, nem poderia conhecer de ofício, quando do julgamento anterior. Nessas especiais circunstâncias, é de ser admitida a propositura de nova ação, cuja causa de pedir, essencialmente factual, não se pode ter como abrangida na de ação anterior, deduzida exclusivamente sob exclusiva fundamentação de direito." (p. 125).

34 "Modificando-se a Constituição, as normas pré-constitucionais ordinárias e, portanto, a força vinculante da sentença que as tenha declarado legítimas subsistem ou não, conforme forem ou não compatíveis com o novo direito. A fonte e o parâmetro da sua validade passam a ser os da nova ordem." (Eficácia das sentenças na jurisdição constitucional. Op. cit., p. 126).
} 
substanciais mudanças da realidade social em que atua" ${ }^{35}$-, mas sem entrar em maiores detalhes acerca das condições que devem ser observadas pelo Supremo quando da revisão das sentenças confirmatórias de constitucionalidade.

\subsection{CONCLUSÕES PARCIAIS}

As lições de Gilmar Mendes e Teori Zavascki, que não encontram posicionamentos divergentes relevantes na doutrina ${ }^{36}$, comprovam o spoiler indicado logo no início deste ensaio, no sentido de que uma decisão em ADC que reconhece a constitucionalidade de determinada norma pode sim ser rediscutida pela via da ADI. Também não parece haver discordância de que mormente cabível, tal possibilidade deve ser manejada com parcimônia, em nome de uma necessária estabilidade - e não imutabilidade - que as decisões do Supremo Tribunal Federal em controle abstrato devem manter.

Sobre o outro questionamento apresentado na introdução deste trabalho, relacionado aos requisitos para que a reanálise da constitucionalidade da norma possa se dar, podemos desdobrar em duas vertentes: (1) quando a quebra da estabilidade da decisão declararatória de constitucionalidade é justificável; e (2) quais requisitos o Supremo deve observar ao se deparar com uma situação dessas, ou seja, como deve se dar a nova análise da (in)constitucionalidade de norma já declarada constitucional.

No que se refere ao ponto (1) acima, Zavascki traz contribuições, excluindo inicialmente a possibilidade de revisão da decisão declaratória de constitucionalidade no caso de rediscussão tão somente com base em fundamentos diversos dos invocados no julgado anterior. Ademais, delimita os contornos do que seria a mudança no estado de direito que justifica a nova análise da norma anteriormente declarada constitucional. Não há, contudo, maiores explanações sobre a hipótese de alteração do estado de fato; ambos os

\footnotetext{
${ }^{35}$ Eficácia das sentenças na jurisdição constitucional. Op. cit., p. 132.

${ }^{36} \mathrm{Na}$ mesma toada de Mendes e Zavascki, Luís Roberto Barroso concorda que não há imutabilidade absoluta na decisão que declara a constitucionalidade de determinada norma. "Parece totalmente inapropriado que se impeça o Supremo Tribunal Federal de reapreciar a constitucionalidade ou não de uma lei anteriormente considerada válida, à vista de novos argumentos, de novos fatos, de mudanças formais ou informais no sentido da Constituição ou de transformações na realidade que modifiquem o impacto ou a percepção da lei." ( $O$ controle de constitucionalidade no direito brasileiro: exposição sistemática da doutrina e análise crítica da jurisprudência. Op. cit., p. 271).
} 
autores mencionam a cláusula rebus sic standibus ${ }^{37}$, mas sem aprofundamento acerca do que efetivamente pode ser considerado como modificação do estado de fato. Tratar-se-ia de alteração de outras normas relacionadas? De modificação da composição da Corte que prolatou a decisão? Ou, mais além, mera mudança de posição dos próprios julgadores que haviam inicialmente declarado a constitucionalidade de determinada norma?

Em relação ao ponto atinente a como deve se dar a nova análise da (in)constitucionalidade de norma já declarada constitucional (2), com as devidas vênias, não há conclusões definitivas. Mendes e Zavascki concordam que eventual decisão que considere inconstitucional uma norma que havia sido declarada constitucional deve observar um ônus argumentativo que justifique a mudança de posição do Supremo. Mas não são elencados outros requisitos e critérios que devem ser adotados em tais casos, tampouco qual o instrumento processual adequado para tanto.

Isso posto, passamos agora a sugerir alternativas para suprir as lacunas acima mencionadas, oportunidade em que buscaremos estabelecer critérios para que, em nome da segurança jurídica, seja mais claro identificar quando e como uma decisão em ADC que reconhece a constitucionalidade de determinada norma pode ser rediscutida pela via da ADI.

\section{EM BUSCA DE CRITÉRIOS PARA A MITIGAÇÃO DA ESTABILIDADE DE DECISÕES DECLARATÓRIAS DE CONSTITUCIONALIDADE}

$\mathrm{O}$ valor vinculante dos precedentes judiciais no ordenamento brasileiro como fonte de segurança jurídica e igualdade para os jurisdicionados, embora sujeito a críticas por parte da doutrina ${ }^{38}$, é uma realidade inexorável. Ada Pellegrini Grinover é expressa ao dizer que

\footnotetext{
${ }^{37}$ A modificação no estado de fato ou de direito (cláusula rebus sic standibus) de determinada relação jurídica de trato continuado pode ser considerada como um limite temporal da coisa julgada, a teor do art. 505, I, do CPC/2015. Exemplo clássico de relação jurídica de trato continuado é o das prestações de alimentos; em um momento inicial o alimentante pode ter condições financeiras para sustentar o alimentando, mas transcorrido certo tempo podem surgir situações fáticas ( $v g$., desemprego) que justifiquem a alteração do que fora inicialmente decidido - e imutabilizado. Há doutrina que considera incorreta a aplicação desta regra na jurisdição constitucional. Georges Abboud aponta que a invocação da cláusula rebus sic standibus seria inadequada para estabelecer os limites da vinculação do Supremo às suas próprias decisões, pois exige "a existência de uma sentença condenatória com prestações periódicas, algo inexistente no processo constitucional de controle abstrato de constitucionalidade, no qual a sentença é declaratória e não existe condenação em prestações periódicas." (Processo constitucional brasileiro, Op. cit., pp. 634-635).

${ }^{38}$ Talvez o crítico mais proeminente seja Lenio Luiz Streck, que condena, dentre diversos outros pontos, o fato de o CPC/2015 estabelecer ex ante quais provimentos judiciais serão considerados precedentes (Precedentes judiciais e hermenêutica, $2^{\mathrm{a}}$ ed., Salvador: Editora JusPodivm, 2019).
} 
"a doutrina já identificou que a eficácia vinculante se ampara em valores essenciais para a ordem jurídica"39, dentre os quais incluem-se, ainda de acordo com a saudosa processualista das Arcadas, "a certeza do direito e a segurança jurídica; a igualdade perante a lei e a garantia constitucional de igual julgamento; a duração razoável do processo; e, acrescentamos, a coerência e unidade do ordenamento jurídico, que o prestigia e o torna mais compreensível aos olhos da sociedade."

As decisões do Supremo Tribunal Federal em controle concentrado de constitucionalidade, como é o caso da ADC, foram positivadas no CPC/2015 como precedentes obrigatórios (art. 927, I). Mas qual a relação disso com o quanto discutido neste artigo?

Ora, Jordi Nieva-Fenoll chama a atenção para que não haja confusão entre coisa julgada e respeito a precedentes obrigatórios. De acordo com o processualista espanhol, “o que pretende a coisa julgada é que não se desvirtue um juízo anterior, e a vinculação ao precedente busca unicamente que os juízos futuros não se desviem de uma determinada linha jurisprudencial." ${ }^{40}$ Demais disso, como alertam Marinoni e Mitidiero falando especificamente sobre a situação de possível novo exame de (in)constitucionalidade de norma anteriormente declarada constitucional, "neste caso, o problema toca no tema da coisa julgada material e não na questão da ratio decidendi ou da eficácia vinculante dos motivos determinantes da decisão de inconstitucionalidade." ${ }^{41}$

Todavia, e retornando ao objeto de estudo deste ensaio, uma decisão do Supremo Tribunal Federal que julgue a procedência de ADC não obtém a autoridade da coisa julgada por completo, pois, conforme visto, isso poderia resultar em pernicioso congelamento da evolução da interpretação constitucional. Assim, até por não haver propriamente a formação de coisa julgada na hipótese, o que defendemos é que a estabilidade que deve carregar tal

\footnotetext{
${ }^{39}$ Ensaio sobre a processualidade: fundamentos para uma nova teoria geral do processo, Op. cit., p. 148. Marinoni cita outras razões para seguir precedentes, dentre as quais $(i)$ desestímulo à litigância e contribuição à duração razoável do processo; (ii) coerência da ordem jurídica; (iii) definição de expectativas; (iv) favorecimento de acordos; ( $v$ ) despersonalização das demandas e maior facilidade de aceitação da decisão; (vi) racionalização do duplo grau de jurisdição; (vii) economia de despesas e maior eficiência do Poder Judiciário. (Luiz Guilherme Marinoni. Precedentes obrigatórios, $5^{\text {a }}$ ed., São Paulo: Editora Revista dos Tribunais, 2016, pp. 96-140).

${ }^{40}$ Coisa Julgada, Op. cit. p. 136.

${ }^{41}$ Luiz Guilherme Marinoni e Daniel Mitidiero. Comentários ao código de processo civil: artigos 926 ao 975. (Coleção comentários ao Código de Processo Civil; coord. Sérgio Cruz Arenhart e Daniel Mitidiero). 2a ed., São Paulo: Thomson Reuters Brasil, 2018, p. 106.
} 
decisão declaratória de constitucionalidade deve ser interpretada vis-à-vis com o dever de estabilidade intrínseco aos precedentes obrigatórios.

Expliquemos em outras palavras: se (1) o CPC/2015 determina que as decisões que consistem em precedentes obrigatórios devem ser estáveis ${ }^{42}$ e (2) a decisão declaratória de constitucionalidade não forma coisa julgada e é um precedente obrigatório (art. 927, I), logo (3) a estabilidade desta decisão pode ser mitigada nas mesmas hipóteses em que um precedente perde seu caráter obrigatório, o que geralmente ocorre mediante a substituição por outro precedente - quando e como isso ocorre é o que nos ocuparemos nos próximos itens.

\subsection{REQUISITOS PARA O CABIMENTO DE NOVA ANÁlISE DE (IN)CONSTITUCIONALIDADE DE NORMA: EXAME DO QUANDO}

$\mathrm{O}$ ordenamento permite que uma norma declarada constitucional em ADC tenha novamente sua constitucionalidade submetida ao crivo do Supremo a fim de evitar a petrificação/fossilização/engessamento do Direito. De modo semelhante, a superação de um precedente obrigatório busca garantir a evolução do Direito. ${ }^{43} \mathrm{O}$ desafio é justamente apontar quando se deve abrir mão da estabilidade das decisões. No âmbito trabalhista, vale destacar a existência de tentativa de sistematizar requisitos para a superação de precedentes, com a inclusão, pela Lei 13.015/2014, do $\$ 17$ ao art. 896-C, da CLT, determinando que

\footnotetext{
${ }^{42}$ Vide Exposição de Motivos do código vigente: “A segurança jurídica fica comprometida com a brusca e integral alteração do entendimento dos tribunais sobre questões de direito. Encampou-se, por isso, expressamente princípio no sentido de que, uma vez firmada jurisprudência em certo sentido, esta deve, como norma, ser mantida, salvo se houver relevantes razões recomendando sua alteração. Trata-se, na verdade, de um outro viés do princípio da segurança jurídica, que recomendaria que a jurisprudência, uma vez pacificada ou sumulada, tendesse a ser mais estável".

${ }^{43}$ A literatura estrangeira, em especial anglo-saxã, é vasta no estudo sobre a temática da superação dos precedentes - ou overruling. De acordo com os norte-americanos James Spriggs e Thomas Hansford: "The overrulling of a precedent, despite its infrequency, is a significant political and legal event, most notably because it represents a dramatic form of legal change. (...) The overruling of a precedent therefore potentially influences social, political, and economic relations as actors alter their behavior based on the new legal rule." (Explaining the overruling of U.S. Supreme Court precedent. The Journal of Politics, Vol. 63, n. 4, Nov./2001, p. 1091-1111). Na doutrina brasileira, Tercio Sampaio Ferraz Jr. destaca que a possibilidade de superação ou alteração de precedentes está intrinsicamente ligada à questão do desenvolvimento do Direito: "Alterações jurisprudenciais fazem parte da dinâmica do direito. Se o processo de mudança legislativa é mais ou menos rígido, se a produção normativa da administração tem uma flexibilidade limitada pela legalidade estrita, é, sem dúvida, na atividade jurisdicional, que o direito conhece seu mais alto grau de adaptabilidade à mudança social, econômica, cultural, no espaço e no tempo". ("Irretroatividade e jurisprudência judicial", in Efeito ex nunc e as decisões do STJ, $2^{\mathrm{a}}$ ed. Barueri: Manole, 2009, p. 4).
} 
"caberá revisão da decisão firmada em julgamento de recursos repetitivos quando se alterar a situação econômica, social ou jurídica (...).”

Retornando à seara cível, em vista do silêncio do legislador, Teresa Arruda Alvim ${ }^{44}$ indica que, embora a jurisprudência deva ser estável, existem basicamente quatro razões para sua alteração: (1) mudança de composição na Corte; (2) mudança de opinião dos (mesmos) julgadores; (3) para que se corrijam erros, reconhecidos abertamente; e (4) necessidade de o Direito adaptar-se às mudanças que há na sociedade. Parece-nos que tais razões podem muito bem ser aplicadas para o exame da possibilidade de nova apreciação de norma já declarada constitucional.

A razão (1) é das mais comuns na jurisdição constitucional. Conforme levantamento feito por Michael Gerhardt com base na Suprema Corte norte-americana, são raras as vezes em que há alteração de precedente firmado pela mesma composição da Corte, de sorte que a troca dos justices aumenta a chance de mudança de precedentes. ${ }^{45}$ Não necessariamente se trata, como aparenta à primeira vista, de um motivo irrazoável. Ainda de acordo com Gerhardt $^{46}$, muitos presidentes nomeiam justices com a esperança e expectativa de que isso vai contribuir para que determinadas questões constitucionais possam ser reapreciadas pela Suprema Corte. Evidentemente que a Suprema Corte, seja nos Estados Unidos ou no Brasil, não é um mecanismo de imposição da vontade da maioria - muito pelo contrário! -, mas não deve ser desprezada a vontade da sociedade (representada no chefe do Poder Executivo) de que uma decisão já tomada ao menos possa ser reanalisada à luz de novos valores e conceitos jurídicos.

O motivo (2) elencado já não é tão defensável. A mera mudança de opinião dos mesmos julgadores, sem qualquer alteração no estado de direito, não é motivo justificável para a reanálise da questão constitucional. Compartilhamos integralmente da posição de Teresa Arruda Alvim na linha de que se trata de hipótese "extremamente criticável e nociva", pois, ainda de acordo com a processualista paulista, "esta alteração, via de regra brusca, não

\footnotetext{
${ }^{44}$ Modulação na alteração da jurisprudência firme ou de precedentes vinculantes, São Paulo: Thomson Reuters Brasil, 2019, pp. 119-129.

45 "In only four cases has a Court with no change in membership overruled itself, and more than half of the overrulings occurred with at least six new justices." (The Power of Precedent, Oxford University Press, 2008, p. 100).

${ }^{46}$ The Power of Precedent, Op. cit., p. 101.
} 
significa, em sentido algum, evolução do direito e inviabiliza de modo definitivo a uniformização, já que impossibilita a estabilização."47

Por outro lado, a razão (3) parece-nos plenamente justificável; se identificado algum grave equívoco $^{48}$ na declaração de constitucionalidade no âmbito de ADC, nada impede que em sede de ADI tal erro seja sanado, até porque não cabe ação rescisória contra a decisão da ADC.

Por fim, a razão (4), que inequivocadamente é a que mais traz discussão. Qual é o busílis? Ora, a dificuldade em estabelecer o que significa o Direito adaptar-se às mudanças da sociedade. Marinoni afirma que uma das razões que justifica a revogação do precedente ocorre quando este deixa de corresponder aos padrões de congruência social, na medida em que passa a negar proposições morais, políticas e de experiência da sociedade e assim frusta as expectativas dos cidadãos. ${ }^{49}$

Trazendo à baila um exemplo concreto, Teresa Arruda Alvim ${ }^{50}$ menciona a discussão sobre a impenhorabilidade do bem de família, prevista na Lei 8.009/1990: a interpretação que prevaleceu durante algum tempo nos Tribunais era de que a regra somente se aplicava às situações em que havia um casal ou entidade familiar, deixando à margem de proteção, portanto, irmãos que moram juntos, viúvos etc. Com o tempo, o entendimento foi sendo alterado, com o Superior Tribunal de Justiça considerando que, para efeito do favor legal, também ficariam fora do alcance da penhora hipóteses diversas, inclusive o devedor solteiro que mora sozinho. De toda forma, em que pese o exame da adaptação do Direito às mudanças da sociedade ser sempre feito caso a caso, ao menos deve se ter em mente a necessidade de que isso ocorra sempre em caráter de exceção, preferencialmente de forma lenta e não brusca. $^{51}$

\footnotetext{
47 "Precedentes e evolução do direito", in Direito Jurisprudencial, São Paulo: Ed. RT, 2012, p. 56.

${ }^{48}$ Sobre a possibilidade de superação fundada em erro na formação do precedente, pertinente a observação de Ravi Peixoto de que "a possibilidade da superação por erro evidente de interpretação deve ser admitida com parcimônia, principalmente em um país marcado por viradas jurisprudenciais constantes, a exemplo do Brasil. No entanto, essa possibilidade não pode ser simplesmente descartada." (Superação do precedente e segurança jurídica, $3^{a}$ ed., Salvador: Editora JusPodivm, 2018, pp. 228-229).

${ }^{49}$ Precedentes obrigatórios. Op. cit., p. 253-254.

${ }^{50}$ Modulação na alteração da jurisprudência firme ou de precedentes vinculantes. Op. cit., pp. 123-124.

${ }^{51}$ Daniel Mitidiero, Precedentes: da persuasão à vinculação, $2^{\mathrm{a}}$ ed., São Paulo: Editora Revista dos Tribunais, 2017, p. 119: "A mudança do precedente não pode causar surpresa injusta (unfair surprise) nem ocasionar um tratamento não isonômico entre pessoas que se encontram temporalmente em situações idênticas ou semelhantes. Nessa linha, o ideal é que a superação do precedente seja sinalizada (signaling) pelo Supremo Tribunal Federal e pelo Superior Tribunal de Justiça para indicar à sociedade civil a possibilidade de mudança de orientação."
} 
Notamos, ao cabo das considerações acima, que mais do que decidir quando há que se falar em hipótese de superação do precedente - ou, de forma análoga, à possibilidade de discussão acerca da (in)constitucionalidade de norma anteriormente declarada constitucional - é mais producente verificar as hipóteses de quando não há que se falar em quebra da estabilidade das decisões. Nesse sentido, existe na doutrina uma discussão sobre uma estabilidade absoluta de precedentes; referimo-nos aos superprecedentes.

A teoria é bastante debatida nos Estados Unidos ${ }^{52}$ e gira em torno da ideia de que determinados precedentes são tão bem elaborados e aceitos pela sociedade que, assim, tornam-se intocáveis. Para os autores norte-americanos que o defendem, seriam exemplos de superprecedentes os casos Marbury v. Madison e Brown v. Board of Education, que definiram, respectivamente, a competência da Suprema Corte dos Estados Unidos para o judicial review e a não segregação de estudantes negros em escolas públicas daquele país.

Replicando a teoria ao caso da decisão de constitucionalidade em ADC, teríamos que determinada decisão - se considerada superprecedente - seria imutável por completo. Ou seja, os efeitos vinculantes originalmente restritos aos demais órgãos do Poder Judiciário e ao Poder Executivo, também se estenderiam ao Poder Legislativo e ao próprio Supremo. Ocorre que o conceito de superprecedentes vem sofrendo diversas críticas, inclusive nos Estados Unidos. ${ }^{53}$ Dessa forma, visto que no Brasil ainda engatinhamos no que se refere à utilização de precedentes em caráter obrigatório, conclui-se que aventar a possibilidade de existência de superprecedentes, isto é, atribuir a certas decisões total imunidade per se às transformações sociais, é medida demasiadamente ousada e prematura.

\subsection{REGRAS A SEREM OBSERVADAS EM NOVA ANÁLISE DE (IN)CONSTITUCIONALIDADE DE NORMA: EXAME DO COMO}

Em consonância com sua linha de maior prestígio aos precedentes, o CPC/2015 contém dispositivos específicos sobre como se deve dar a superação de um precedente - e, consequentemente, também aplicáveis na hipótese de o Supremo Tribunal Federal apreciar em sede de ADI a (in)constitucionalidade de norma que havia sido declarada constitucional

\footnotetext{
52 "Some precedentes as being so deeply embedded in our law and culture that they have become practically immune to overturning." (Michael J. Gerhardt, The Power of Precedent, Op. cit., p. 177).

${ }^{53}$ Sobre os riscos em atribuir efeitos imutáveis eternos a decisões, v. Randy Barnett, "It's a Bird, It's a Plane, No, It's Super Precedent: A Response to Farber and Gerhardt". Minnesota Law Journal, v. 90, pp. 1.232-1.251, 2006.
} 
por meio de sentença de procedência em ADC. Referimo-nos às previsões de (1) audiências públicas e participação de interessados na rediscussão da questão constitucional ${ }^{54}$; (2) necessidade de ônus argumentativo específico a justificar a mudança de entendimento da Corte $^{55}$; e (3) possibilidade de modulação dos efeitos da nova decisão. ${ }^{56}$

Acerca do item (1), cabe, inicialmente, relembrar as palavras de Peter Haberle: "todo aquele que vive no contexto regulado por uma norma e que vive com este contexto é, indireta ou, até mesmo diretamente, um intérprete dessa norma. (...) Como não são apenas os intérpretes jurídicos da Constituição que vivem a norma, não detêm eles o monopólio da interpretação da Constituição." ${ }^{57}$ Haberle, aliás, cita expressamente a realização de audiências e "intervenções" como forma de concretizar a maior participação na jurisdição constitucional.

Com essa premissa em mente, chegamos ao primeiro requisito que deve ser observado pelo Supremo caso entenda pela reanálise de lei declarada constitucional, que é a obrigatoriedade de divulgação intensiva da possibilidade de mudança de entendimento sobre a norma em debate e a intimação expressa de todos os sujeitos e entes (autores, eventuais amici curiae e participantes de audiências ocorridas) que de alguma forma participaram do processo de ADC que culminou na declaração de constitucionalidade da norma. ${ }^{58}$

\footnotetext{
54 “Art. 927. Os juízes e os tribunais observarão: (...) §2 A alteração de tese jurídica adotada em enunciado de súmula ou em julgamento de casos repetitivos poderá ser precedida de audiências públicas e da participação de pessoas, órgãos ou entidades que possam contribuir para a rediscussão da tese."

55 " $\$ 4^{\circ} \mathrm{A}$ modificação de enunciado de súmula, de jurisprudência pacificada ou de tese adotada em julgamento de casos repetitivos observará a necessidade de fundamentação adequada e específica, considerando os princípios da segurança jurídica, da proteção da confiança e da isonomia."

56 “ $\$ 3^{\circ} \mathrm{Na}$ hipótese de alteração de jurisprudência dominante do Supremo Tribunal Federal e dos tribunais superiores ou daquela oriunda de julgamento de casos repetitivos, pode haver modulação dos efeitos da alteração no interesse social e no da segurança jurídica."

${ }^{57}$ Hermenêutica constitucional: a sociedade aberta dos intérpretes da constituição - contribuição para a interpretação pluralista e procedimental da constituição, Porto Alegre: Safe, 2002, p. 15.

${ }^{58}$ Isso é particulamente importante em vista de determinadas situações em que o Supremo altera "de surpresa" um entendimento fixado em controle abstrato de constitucionalidade. Tomemos como exemplo caso de Reclamação em que a Corte, mesmo reconhecendo que a oportunidade de reapreciação de constitucionalidade de norma dependeria da propositura de nova ação direta contra o preceito anteriormente declarado constitucional, acabou por aceitar a reapreciação da decisão no âmbito de reclamação, mesmo não identificando tal previsão no rol das possibilidade de cabimento de reclamações previsto no art. 988 do CPC/2015 (que em seu inciso III prevê a possibilidade de reclamação para garantir a observância de decisão do Supremo em controle concentrado de constitucionalidade, o que é muito diferente de se interpretar como um permissivo para alterar um entendimento firmado em controle concentrado de constitucionalidade). Pela importância da decisão, transcrevemos parte de sua ementa: "Reclamação como instrumento de (re)interpretação da decisão proferida em controle de constitucionalidade abstrato. (...) A oportunidade de reapreciação das decisões tomadas em sede de controle abstrato de normas tende a surgir com mais naturalidade e de forma mais recorrente no âmbito das reclamações. É no juízo hermenêutico típico da reclamação - no "balançar de olhos" entre objeto e parâmetro da reclamação - que surgirá com maior nitidez a oportunidade para evolução interpretativa no controle de constitucionalidade. Com base na alegação de afronta a determinada decisão do
} 
Naturalmente, não caberá ao Supremo negar a participação no processo de rediscussão da constitucionalidade da norma de quem havia atuado no primeiro processo.

Isso posto, cabem duas ressalvas importantes. Primeiro que o texto do $\S 2^{\circ}$ do art. 927 do CPC/2015, em pobre redação legislativa, fala em alteração da tese jurídica adotada em enunciado de súmula ou em julgamento de casos repetitivos, mas é evidente que a norma também se destina ao caso de rediscussão de algo decidido em controle concentrado de constitucionalidade. Além disso, o termo poderá contido no dispositivo não deve ser interpretado como uma faculdade, mas sim como um comando imperativo - a alteração da tese jurídica deverá ser precedida de audiências públicas e da participação de pessoas, órgãos ou entidades que possam contribuir para a rediscussão da tese, pois a participação destes como intérpretes constitucionais é fundamental para uma decisão mais justa possível.

Dá suporte a esse entendimento a doutrina clássica de Carlos Maximiliano, que ao examinar a controvérsia de que os termos pode e deve nem sempre exprimem coisas diferentes, conclui que "se, ao invés do processo filológico de exegese, alguém recorre ao sistemático e ao teleológico, atinge, às vezes, resultado diferente: desaparece a antinomia verbal, pode assume as proporções e o efeito do deve. ${ }^{" 59}$ Ora, seja pela via dos amici curiae, que podem trazer aos julgadores visões diferentes da questão em controvérsia, ou pela realização de audiências públicas ${ }^{60}$, é certo que a participação da sociedade nos processos de jurisdição constitucional é um objetivo do nosso ordenamento para plurificar o debate, pelo que se justifica o caráter mandatório, e não meramente facultativo, da regra aqui defendida.

Outra regra impositiva (esta com o deverá - no caso observará - expresso no texto legal) é que o Supremo deve respeitar o chamado ônus argumentativo (2), caso entenda pela necessidade de alterar o entendimento inicial, ou seja - e considerando a questão posta em debate neste ensaio -, quando declarar a inconstitucionalidade da norma que havia recebido o "selo" de constitucionalidade em ADC anterior.

STF, o Tribunal poderá reapreciar e redefinir o conteúdo e o alcance de sua própria decisão. E, inclusive, poderá ir além, superando total ou parcialmente a decisão-parâmetro da reclamação, se entender que, em virtude de evolução hermenêutica, tal decisão não se coaduna mais com a interpretação atual da Constituição." (Rcl 4374, Rel. Min. Gilmar Mendes, Tribunal Pleno, j. em 18/04/2013).

${ }^{59}$ Hermenêutica e aplicação do direito. $20^{\mathrm{a}}$ ed., Rio de Janeiro: Forense, 2011, pp. 220-221.

60 "Das audiências públicas participam setores da sociedade que lá defendem seus pontos de vista, em evidente ambiente democrático. Muitas vezes, destas audiências participam economistas, médicos, representantes de sindicatos, dependendo do tema sobre o qual versa o processo." (Teresa Arruda Alvim, Modulação na alteração da jurisprudência firme ou de precedentes vinculantes. Op. cit., p. 186). 
No direito norte-americano, essa exigência tem como fundamento, além dos princípios da segurança jurídica, da proteção da confiança e da isonomia, o fato de que alterar o precedente nunca pode ser entendido como algo trivial. Em relativamente recente julgado da Suprema Corte daquele país, instada a alterar um precedente, a negativa da Corte foi justificada em uma frase bem conhecida da cultura moderna: com grandes poderes vêm grandes responsabilidades. ${ }^{61}$ Mas também no Brasil existem exemplos de situações em que o Supremo reconheceu que a superação de precedentes não é uma situação corriqueira. Lembremos, nesse sentido, que em 2015 o tribunal negou pedido de revisão do Enunciado 11 da Súmula Vinculante ("súmula das algemas") exatamente por considerar que o proponente da revisão não se desincumbiu do ônus de demonstrar os motivos da necessidade de revisão da súmula. ${ }^{62}$

Este ônus argumentativo impõe que o Supremo exponha minuciosamente os motivos pelos quais a nova posição é constitucionalmente mais adequada que a superada. ${ }^{63}$ Não se trata de simplesmente defender a nova posição, mas sim de demonstrar as razões da alteração $^{64}$, ou seja, quais foram as mudanças de fato ou direito que ensejaram na quebra da estabilidade da decisão inicial, evento que por óbvio prejudica a segurança jurídica que serve (ou deveria servir) de sustento ao ordenamento jurídico.

Finalmente, chegamos (3) ao último aspecto a ser examinado que, diferentemente dos dois anteriores, não consiste em obrigação do Supremo Tribunal Federal, mas sim de uma faculdade. Trata-se da possibilidade de modulação dos efeitos da decisão, que inibe a

\footnotetext{
${ }^{61}$ Essa frase foi retirada de voto proferido no julgamento do caso Kimble v. Marvel Entertainment (2015): "What we can decide, we can undecide. But stare decisis teaches that we should exercise that authority sparingly. Cf. S. Lee and S. Ditko, Amazing Fantasy No. 15: 'SpiderMan,' p. 13 (1962) ('[I]n this world, with great power there must also come great responsibility'). Finding many reasons for staying the stare decisis course and no 'special justification' for departing from it, we decline Kimble's invitation to overrule Brulotte." ${ }^{62} C f$. informativo n. 800 do Supremo Tribunal Federal, de 21 a 25 de setembro de 2015: "A Corte asseverou que, para admitir-se a revisão ou o cancelamento de súmula vinculante, seria necessário demonstrar: a) a evidente superação da jurisprudência do STF no trato da matéria; b) a alteração legislativa quanto ao tema; ou, ainda, c) a modificação substantiva de contexto político, econômico ou social. A proponente, porém, não teria comprovado a existência dos aludidos pressupostos, assim como não teria se desincumbido do ônus de apresentar decisões reiteradas do STF que demonstrassem a desnecessidade de vigência do enunciado em questão, o que impossibilitaria o exame da presente proposta de cancelamento. Por fim, cumpriria destacar que o mero descontentamento ou eventual divergência quanto ao conteúdo de verbete vinculante não autorizariam a rediscussão da matéria. PSV 13/DF, 24.9.2015. (PSV-13)."

${ }^{63}$ Georges Abboud, Processo constitucional brasileiro, 2019, p. 640.

${ }^{64}$ Luiz Guilherme Marinoni. Precedentes obrigatórios, Op. cit., p. 358: "Para revogar precedente ou dar nova regulação ao caso, é preciso demonstrar que as antigas razões não mais podem prevalecer. O colegiado, para revogar um precedente, tem um pesado ônus argumentativo. Não basta que demonstre que as suas razões são boas; cabe-lhe evidenciar que as antigas razões não podem subsistir em face das suas novas razões."
} 
incidência da regra geral ex tunc das decisões declaratórias de inconstitucionalidade. Como é tradição em nosso ordenamento, o reconhecimento da inconstitucionalidade significa dizer que há uma nulidade na origem da norma. Somente em excepcionais circunstâncias, verificadas de forma casuística, é que se pode cogitar na manutenção (temporária) de determinada situação inconstitucional. Nas lições de Teori Zavascki, "em casos tais, cumpre ao STF efetuar o juízo de ponderação entre os valores jurídicos colidentes (inconstitucionalidade da norma, de um lado, e segurança jurídica ou excepcional interesse social, de outro), a fim de harmonizá-los no mais elevado grau de viabilidade e, se indispensável, promovendo os ajustes limitativos na eficácia (executiva) da declaração de inconstitucionalidade. ${ }^{.65}$

Embora haja doutrina que defende que a modulação deve sempre ocorrer ${ }^{66}$, o fato é que a previsão de modulação específica para decisões em controle de constitucionalidade, constante do art. 27 da Lei 9.882/1999 ${ }^{67}$, corrobora o caráter de excepcionalidade da medida, inclusive em razão do quórum qualificado que é exigido para que a modulação ocorra.

Não é tarefa fácil a definição sobre quando efetivamente o Supremo pode cogitar a utilização do instrumento da modulação ${ }^{68}$, até porque conforme exposto, trata-se de análise que envolve prioritariamente a situação do caso concreto. De toda forma, alguns critérios levantados por Teresa Arruda Alvim ${ }^{69}$ nos parecem úteis para enfrentar o tema, também pela perspectiva da modulação de decisão em controle de constitucionalidade.

De acordo com Arruda Alvim, um dos critérios para identificar casos em que a modulação deve ocorrer é a necessidade de proteção da confiança que teve o jurisdicionado em firme orientação anterior; ou seja, mudanças bruscas que surpreendem o jurisdicionado pedem modulação, ao passo que um cenário de jurisprudência desencontrada e dispersa não

\footnotetext{
${ }^{65}$ Eficácia das sentenças na jurisdição constitucional. Op. cit., p. 69.

${ }^{66}$ Georges Abboud, Processo constitucional brasileiro, Op. cit., p. 640: "Sempre quando o STF entender que é o caso de se afastar, desvinculando-se de sua decisão anterior e modificando sua interpretação, além de possuir o dever da fundamentação, essa nova decisão modificativa de decisões anteriores deverá, em regra, ter eficácia ex nunc para se preservar a segurança jurídica e a boa-fé objetiva em relação ao jurisdicionado.”

67 "Art. 27. Ao declarar a inconstitucionalidade de lei ou ato normativo, e tendo em vista razões de segurança jurídica ou de excepcional interesse social, poderá o Supremo Tribunal Federal, por maioria de dois terços de seus membros, restringir os efeitos daquela declaração ou decidir que ela só tenha eficácia a partir de seu trânsito em julgado ou de outro momento que venha a ser fixado."

${ }^{68}$ Discorrendo sobre a a dificuldade na criação de parâmetros para a identificação de quais casos a superação dos precedentes deve ser modulada, Ravi Peixoto afirma que por vezes haverá uma "zona de penumbra" a dividir opiniões favoráveis e contrárias à modulação, mas que de qualquer forma deve ser vedado ao Judiciário optar pela modulação tão somente com base em argumentos vagos e imprecisos (Superação do precedente $e$ segurança jurídica, Op. cit., p. 340).

${ }^{69}$ Modulação na alteração da jurisprudência firme ou de precedentes vinculantes. Op. cit., pp. 157-189.
} 
gera confiança a prestigiar e, portanto, não justifica a modulação. Outro critério que também exige modulação, muito comum em causas tributárias, dá-se na prevalência de direitos de particulares em detrimento do interesse público - "se a nova posição prejudicar o particular, deve haver modulação. Não deve o particular arcar com os ônus decorrentes da incoerência da conduta dos representantes do Estado." 70

\section{CONCLUSÕES}

Ao longo do presente ensaio, procuramos demonstrar, a partir do recorte temático escolhido, como funciona a regra de estabilidade da decisão na jurisdição constitucional que declara a constitucionalidade de determinada norma. Se por um lado verificamos que não há imutabilidade absoluta (coisa julgada) em tais decisões - e existem boas razões para tanto, basicamente relacionadas a impedir o congelamento da evolução do Direito -, por outro vislumbramos que o princípio da segurança jurídica exige que haja certa estabilidade em torno das decisões declaratórias de constitucionalidade. Dessa necessidade de estabilidade decorre, por exemplo, a produção de efeitos vinculantes dessas decisões, somente não oponíveis ao Poder Legislativo e ao próprio Supremo Tribunal Federal.

A manifestação do então Ministro Carlos Velloso logo nas discussões da primeira ADC submetida ao Supremo - hoje, a lei pode ser constitucional, amanhã, não - não está incorreta, mas deve ser encarada com ressalvas. Isso porque, o dever geral de estabilidade das decisões, ainda mais presente na jurisdição constitucional, exige que certos requisitos sejam observados para a rediscussão de sentença de procedência em ADC. Na ausência de definição sobre o quando isso deve se dar, procuramos sugerir, sem quaisquer pretensões de esgotamento de tema tão complexo quanto o estudado, a possibilidade de se considerar as regras atinentes a superação de precedentes como parâmetros também para os casos de reapreciação da (in)constitucionalidade de norma anteriormente declarada constitucional.

Por fim, e não menos importante, ultrapassada a primeira barreira de admissibilidade de nova discussão da norma pelo Supremo Tribunal Federal, verificamos que as condições que a Corte deve observar no novo julgamento em controle abstrato são, no mínimo, aquelas elencadas nos parágrafos do art. 927 do CPC/2015, quais sejam, necessidade de realização de audiências públicas e participação de pessoas, órgãos e entidades que contribuam para a

\footnotetext{
${ }^{70}$ Modulação na alteração da jurisprudência firme ou de precedentes vinculantes. Op. cit., p. 166.
} 
rediscussão da tese, obrigação de o Supremo suportar ônus argumentativo para justificar as razões pelas quais a decisão anterior sobre a constitucionalidade da norma deve ser revista, e, finalmente, a possibilidade de modulação de efeitos da nova decisão, por razões de interesse social e segurança jurídica.

\section{REFERÊNCIAS}

ABBOUD, Georges. Processo constitucional brasileiro. $3^{\mathrm{a}}$ ed., São Paulo: Thomson Reuters Brasil, 2019.

ARRUDA ALVIM, Teresa. Modulação na alteração da jurisprudência firme ou de precedentes vinculantes. São Paulo: Thomson Reuters Brasil, 2019.

. Precedentes e evolução do direito. In: Direito Jurisprudencial. São Paulo: Ed. RT, 2012, p. 56.

BARNETT, Randy. "It's a Bird, It's a Plane, No, It's Super Precedent: A Response to Farber and Gerhardt". In: Minnesota Law Journal, v. 90, pp. 1.232-1.251, 2006.

BARROSO, Luís Roberto. $O$ controle de constitucionalidade no direito brasileiro: exposição sistemática da doutrina e análise crítica da jurisprudência. $8^{\mathrm{a}}$ ed., São Paulo: Saraiva, 2019.

CABRAL, Antonio do Passo. Coisa julgada e preclusões dinâmicas: entre continuidade, mudança e transição de posições processuais estáveis. $2^{\mathrm{a}}$ ed., Salvador: JusPodivm, 2014.

As estabilidades processuais como categoria incorporada ao sistema do CPC. In: DIDIER JR., Fredie; CABRAL, Antonio do Passo. Coisa julgada e outras estabilidades processuais. Salvador: Ed. JusPodivm, 2018.

DINAMARCO, Cândido Rangel. Instituições de direito processual civil: volume III. $8^{\mathrm{a}}$ ed., São Paulo: Malheiros, 2019.

FERRAZ JR., Tercio Sampaio. Irretroatividade e jurisprudência judicial. In: Efeito ex nunc e as decisões do STJ. $2^{\mathrm{a}}$ ed. Barueri: Manole, 2009.

GERHARDT, Michael J. The Power of Precedent. Oxford University Press, 2008.

GRINOVER, Ada Pellegrini. Ensaio sobre a processualidade: fundamentos para uma nova teoria geral do processo. Brasília: Gazeta Jurídica, 2018. 
HABERLE, Peter. Hermenêtica constitucional: a sociedade aberta dos intérpretes da constituição - contribuição para a interpretação pluralista e procedimental da constituição. Trad. de Gilmar Ferreira Mendes. Porto Alegre: Safe, 2002.

HESSE, Konrad. A força normativa da constituição. Trad. de Gilmar Ferreira Mendes. Porto Alegre: Safe, 1991.

MARINONI, Luiz Guilherme. A intangibilidade da coisa julgada diante da decisão de inconstitucionalidade: art. 525, §§ 12, 13, 14 e 15 do CPC/2015. $4^{\text {a }}$ ed., São Paulo: Editora Revista dos Tribunais, 2016.

Precedentes obrigatórios. $5^{\mathrm{a}}$ ed., São Paulo: Editora Revista dos Tribunais, 2016.

; MITIDIERO, Daniel. Comentários ao código de processo civil: artigos 926 ao 975. (Coleção comentários ao Código de Processo Civil; coord. Sérgio Cruz Arenhart e Daniel Mitidiero). $2^{\text {a }}$ ed., São Paulo: Thomson Reuters Brasil, 2018.

MAXIMILIANO, Carlos. Hermenêutica e aplicação do direito. $20^{\mathrm{a}}$ ed., Rio de Janeiro: Forense, 2011.

MENDES, Gilmar Ferreira. Jurisdição constitucional: o controle abstrato de normas no Brasil e na Alemanha. $6^{a}$ ed., São Paulo: Saraiva, 2014.

; ABBOUD, Georges. Ativismo judicial: notas introdutórias a uma polêmica contemporânea. In: Revista dos Tribunais, vol. 1008, Out./2019.

MITIDIERO, Daniel. Precedentes: da persuasão à vinculação. $2^{\mathrm{a}}$ ed., São Paulo: Editora Revista dos Tribunais, 2017.

NIEVA-FENOLL, Jordi. Coisa Julgada. Trad. de Antonio do Passo Cabral. São Paulo: Editora Revista dos Tribunais, 2016.

PEIXOTO, Ravi. Superação do precedente e segurança jurídica. $3^{\mathrm{a}}$ ed., Salvador: Editora JusPodivm, 2018.

ROSSONI, Igor Bimkowski. Coisa julgada e controle de constitucionalidade. Dissertação de mestrado apresentada à Faculdade de Direito da Universidade de São Paulo, 2013. SPRIGGS, James F; HANSFORD, Thomas. Explaining the overruling of U.S. Supreme Court precedent. The Journal of Politics, Vol. 63, n. 4, Nov./2001, p. 1091-1111.

STRECK, Lenio Luiz. Precedentes judiciais e hermenêutica, $2^{\mathrm{a}}$ ed., Salvador: Editora JusPodivm, 2019. 
Revista Eletrônica de Direito Processual - REDP

Rio de Janeiro. Ano 15. Volume 22. Número 1. Janeiro a Abril de 2021

Periódico Quadrimestral da Pós-Graduação Stricto Sensu em Direito Processual da UERJ

Patrono: José Carlos Barbosa Moreira (in mem.). ISSN 1982-7636. pp. 29-57

www.redp.uerj.br

THAMAY, Renann Faria Kruger. A coisa julgada no controle de constitucionalidade abstrato. São Paulo: Atlas, 2015.

ZAVASCKI, Teori Albino. Eficácia das sentenças na jurisdição constitucional. $4^{\mathrm{a}}$ ed., São

Paulo: Editora Revista dos Tribunais, 2017. 